\title{
Impact of firms specific on the financial performance of Indian firms
}

\section{Dheya A. Zaid ${ }^{1}{ }^{\text {, }}$ Dr. Irfan Ahmad ${ }^{2}$}

${ }^{1}$ Research scholar, Department of Commerce, Aligarh Muslim University, Aligarh, 202002, India.

${ }^{2}$ Associate Professor, Department of Commerce, Aligarh Muslim University, Aligarh, 202002, India.

\begin{tabular}{|c|c|c|c|}
\hline Received: 20.12 .2020 & Accepted: 23.12 .2020 & Published: 24.12 .2020 & $\begin{array}{ll} & \text { Final Version: } 24.12 .2020\end{array}$ \\
\hline
\end{tabular}

\begin{abstract}
The main aim of this article is to examine the effect of firms' specific on the financial performance of Indian firms. The study is based on 1069 firms listed on the Bombay stock exchange for the period from 2011 to 2017. Descriptive statistics, correlation matrix, and regression models are used for analyzing the data. The study found that cost of financial distress, growth opportunities, firms size, and total taxes positively and significantly impact the financial performance of Indian firms measured by return on assets and return on capital employed. On the contrary, asset structure and leverage negatively and significantly impact the financial performance of Indian firms. Most previous studies were based on small samples; this article bridges an existing gap in the literature by covering large data of 1069 firms for seven years which make the results of the study to be generalized. The findings of this study have useful implications for policymakers, practitioners, and academicians.
\end{abstract}

Keywords: financial performance; financial distress; growth opportunities; firms' size; total taxes.

\section{Introduction}

Most organizations have started their businesses in order to earn profit and provide their shareholders with sufficient income in exchange. Profitability can essentially be described as the measure at which an organization can make the most of its available funds and assets successfully and efficiently, as well as transform them into outstanding profits. (Devi A \& Devi S, 2014) Advocate that profitability helps companies to improve their market climate by enhancing negative shocks and investing in improving them. It was possible to determine the importance of corporate profitability at 2 stages, that is, macro and micro of the financial sector. The critical prerequisite of an indomitable enterprise and the cheap resource of capital is micro-level return.

According to Bobakova (2003), the management of an organization must realize a profit for carrying out every business. At the macro stage, cost-effective and profitable market environments are strengthened and continue to improve the business climate. For this reason, studies in the fields of economics, corporate strategy, accounting, marketing and finance have found the assessment of the variables influencing firm profitability and the identification of sources of differentiation in company-level profitability as core research topics (Jonsson, 2007; Nunes, 2009; Gaur \& Gupta, 2011).

Organizations in growth economies are typically expected to perceive critical obligation and their success is one of the most relevant concerns for many business stakeholders such as stakeholders, creditors, workers, vendors and governments (Bhayani, 2010; Madrid, Auken \& Perez, 2007) For a corporation to stay in operation and to survive competition from businesses competing in related markets, optimizing profit is a very important

* Corresponding Author: E- Mail: dheya3@yahoo.com 
goal. It is a significant prerequisite for a company's long-term sustainability and growth, while it is a primary precondition for achieving a corporate entity's other financial objectives (Gitman \& Zutter, 2012).

Profitability is a primary indicator of a company's success and constitutes an important component of its financial statements. It indicates the capacity and ability of the company to produce profits at a revenue rate, asset level, and capital stock in a particular time period (Margaretha \& Supartika, 2016). As a result, the viability of businesses and ways of developing them have created significant literature disputes and become topical in the fields such as finance, economics, accounting, and management. Profitable companies raise the value, recruit workers, strive to be more creative, more economically conscious, and support the country as a whole by paying taxes. Strong business production rates contribute successfully to the generation of profits and the economic growth of an economy (Olutunla \&Obamuyi, 2008; Lazar, 2016). Different studies have been conducted in India and reported that there is a dearth (e.g, Al-Homaidi, E. A., Almaqtari, 2020; Al-Homaidi, E. A., Tabash, 2018; Almaqtari, F. A., Al-Homaidi, 2019; Almaqtari \& Shamim et al., 2020; Almaqtari \& Al-Hattami et al., 2020; Al Maqtari \& Farhan et al., 2020; Almaqtari, F. A., Farhan; 2020; Farhan, N. H., Alhomidi, 2019; Farhan, N., Tabash, 2020; Almaqtari, F. A., Hashid, 2020). The main aim of the present study is to examine the effect of firms' specific on the financial performance of Indian firms. Accordingly, the present study is organized as follows: section 2 provides literature review. Section 3 presents Research methodology. Section 4 Analysis and discussion, and Section 5 provides Conclusion

\section{Literature review}

Discussions on the performance of businesses usually calculated by profitability have hovered around selected concepts. Osuji and Odita (2012) noted the effect of the capital structure on the economic positions of a sample of 30 Nigerian non-financial entities listed on the Nigerian Stock Exchange between 2004 and 2010. Panel data were obtained and analyzed by the methodology of ordinary least squares (OLS). The result interprets that the capital structure of a company surrogated by the leverage ratio has a major detrimental impact on the financial performance of the company calculated by the return on assets (ROA).

The interaction among capital structure, scale, growth, age, tangibility, and profitability of an organization was investigated by Ogbulu and Emeni (2012). Used a cross-sectional analysis of the data from 110 companies listed on the Nigerian stock exchange, and an OLS process analysis of the data, the relationship among capital structure and profitability was insignificant, although optimistic. Odusanya et al. (2018), analyses profitability patterns and addresses some of the main macro and micro-level factors impacting the Indian logistics industry, including road transport logistics, storage, and distribution. The result found that liquidity, debt-equity, market share, and age are critical determinants of logistics sector profitability.

Gill and Mathur (2011) acknowledged the variables that have affected Canadian corporations' financial leverage. Profitability considered by Yields on Investment was in the center of these variables (ROA). For a three - year period, a sample of 166 companies from Canada listed on the Toronto Stock Exchange was preferred (2008 to 2010). The functional relationship of analysis and the non-experimental nature of the analysis. Their findings indicate a non-significant negative association between profitability and financial leverage. The determinants of the profitability of Pakistani companies have been established by Devi and Devi (2014). Financial leverage, capital structure, company size, and corporate profitability are the factors used in this analysis. Data were obtained from 50 firms on the Karachi Stock Exchange website for a period of 7 years. This research shows a strong connection between financial leverage, corporate profitability, business size, and corporate profitability.

Daare (2016) defined variables that assess the profitability of non-life insurance firms in India. Achieving the objective financial report of 8 general insurance companies ( 6 private and 2 public companies) compiled between 2006 and 2016. The study suggested that insurance managers pay particular attention to the management of existing assets and current liabilities in order to maintain an optimum liquidity role, while inflation from external factors is also relevant. Al-Jafari \& Samman (2015) examined the profitability determinants for manufacturing 
companies in Oman. A survey of 17 manufacturing companies listed on the Muscat stock exchange was used, covering the period 2006 to 2013. The research concluded that big, increasing businesses with effectively operated funds raise sales and eventually maximize profitability. In the period from 2001 to 2008, Bhayani (2010) examined variables impacting profitability for cement companies. He stated that the Indian cement industry's liquidity, operating ratio, company age, interest rate, and inflation are important profitability determinants.

The determinants of profitability for Indian life insurance firms have been investigated by Charumathi (2012). The findings offered proof of a positive and essential link between size, liquidity, and profitability. However, it has been found that debt, premium growth, and equity capital have a negative and serious impact on profitability. Mistry (2012) studied the Indian automotive industry over a period of five years. The results show a favorable and critical relationship between size, debt to equity ratio and inventory turnover ratio in most years. The company's liquidity was found to have a significant and negative correlation with profitability.

Al-Jafari and Alchami (2014) analyzed the profitability determinants of Syrian banks using the Generalized Moment Method (GMM) methodology. Their findings show that the profitability of Syrian banks is greatly influenced by the liquidity ratio, bank size, credit risk, and management performance. Likewise, for 55 Sri Lankan manufacturing firms using static panel templates, Pratheepan (2014) evaluated the profitability determinants. The findings suggest that size has a major positive profitability association. Therefore, tangibility has been shown to have an opposite statistical correlation with profitability. But at the other hand, debt and liquidity have been shown to have an insignificant impact on profitability. The viability of Bangladesh's pharmaceutical firms was investigated by Bashar and Islam (2014). They suggested that it had a positive and valuable impact on profitability to handle inventory effectively.

\section{Research methodology}

The target population of the study is all non-financial firms listed on Bombay stock exchange, there are almost 4056 non-financial firms listed on Bombay stock exchange. The study eliminated firms that do not have data for the study period from 2011 to 2017 and studies that have mission values, there for the final sample of the study is 1069 firms which do not have even one single missing value. Data has been collected using various sources like books, journals, and annual reports extract financial details from the ProwessQ database (the largest database focusing exclusively on Indian companies' financial performance).

There are two variables; the independent variable is firms' specific which includes cost of financial distress, growth opportunities, firms size, total taxes, asset structure, and leverage, while the dependent variable is firm's performance, which was measured by return on assets, return on capital employed and return on net worth. The researcher uses a panel regression approach to analyze the impact of firms specific (independent variable) on firms' financial performance (dependent variable) of Indian firms listed on BSE. The estimated model is based on 1069 companies with 7483 years observation for the period from 2011 to 2017. The following are the regression models which have been used.

$$
\begin{aligned}
& (\mathrm{ROA})_{\mathrm{it}=} \alpha+\beta_{1}(\mathrm{AS})_{\mathrm{it}}+\beta_{2}(\mathrm{COFD})_{\mathrm{it}}+\beta_{3}(\mathrm{GO})_{\mathrm{it}}+\beta_{4}(\mathrm{Size})_{\mathrm{it}}+\beta_{5}(\mathrm{TTAX})_{\mathrm{it}}+\beta_{6}(\mathrm{LEV})_{\mathrm{it}}+\varepsilon_{\mathrm{it}} \\
& (\mathrm{ROCE})_{\mathrm{it}=} \alpha+\beta_{1}(\mathrm{AS})_{\mathrm{it}}+\beta_{2}(\mathrm{COFD})_{\mathrm{it}}+\beta_{3}(\mathrm{GO})_{\mathrm{it}}+\beta_{4}(\mathrm{Size})_{\mathrm{it}}+\beta_{5}(\mathrm{TTAX})_{\mathrm{it}}+\beta_{6}(\mathrm{LEV})_{\mathrm{it}}+\varepsilon_{\mathrm{it}} \\
& (2) \\
& (\mathrm{RONW})_{\mathrm{it}=} \alpha+\beta_{1}(\mathrm{AS})_{\mathrm{it}}+\beta_{2}(\mathrm{COFD})_{\mathrm{it}}+\beta_{3}(\mathrm{GO})_{\mathrm{it}}+\beta_{4}(\mathrm{Size})_{\mathrm{it}}+\beta_{5}(\mathrm{TTAX})_{\mathrm{it}}+\beta_{6}(\mathrm{LEV})_{\mathrm{it}}+\varepsilon_{\mathrm{it}}(3)
\end{aligned}
$$

Where:

$(\mathrm{ROA})$ it $=$ Stands for financial performance of company I, at time $t$, measured by return on assets .

(ROCE) it $=$ Return on capital employed I, at time $t$.

$(\mathrm{RONW})$ it $=$ Return on net worth

$(\mathrm{AS})_{\mathrm{it}}=$ Asset structure $\mathrm{i}$ at time $\mathrm{t}$.

$(\mathrm{COFD})_{\mathrm{it}}=$ Cost of financial distress 
$(\mathrm{GO})_{\text {it }}$ = Growth opportunities

$(\text { TTAX })_{\text {it }}=$ Total taxes

$(\text { Size })_{\text {it }}=$ Size of firm $i$ at time $t$.

$(\mathrm{LEV})_{\text {it }}=$ Leverage of company $i$ at time $t$.

$(\alpha)=$ Common $y$-intercept.

$(\beta 1-\beta 6)=$ Coefficients of the explanatory variables

$(\varepsilon)_{\text {it }}=$ Stochastic error term of company $i$ at time t. Following table (1) which defines the variables of the study

Table 1. Variables description

\begin{tabular}{lcl}
\hline \multicolumn{1}{c}{ Proxy } & Symbol & \multicolumn{1}{c}{ Formula } \\
\hline $\begin{array}{l}\text { Return on assets } \\
\begin{array}{l}\text { Return on capital } \\
\text { employed }\end{array}\end{array}$ & ROA & Net income divided by total assets at the end of the year. \\
Return on net worth & RONW & Earnings before interest and tax divided by Capital Employed \\
Cost of financial distress & COFD & $\begin{array}{l}\text { Subtract the cost of debt rated company from the weighted average cost of } \\
\text { debt. }\end{array}$ \\
growth opportunities & GO & Tobin's Q \\
firms size & Size & Natural logarithm of total assets \\
total taxes & TTAX & Total tax of the year \\
asset structure & AS & Fixed assets divided by total assets \\
leverage & LEV & Total debt /shareholder's equity
\end{tabular}

\section{Analysis and discussion}

\subsection{Descriptive statistics}

The central tendency is seen in Table (2) for all variables included in the study, which are illustrated as follow: the mean values of firms' profitability are 3.212, 4.508 and 5.305 for ROA, ROCE, and RONW, respectively, with 6.250, 9.098 and 50.751 standard deviation respectively. Regarding firms specific, the mean values of AS, COFD, GO, SIZE, TTAX and LEV are 0.754, -173.950, 19.432, 3.599, 2635.373 and 1.745.

Table 2. Descriptive statistics

\begin{tabular}{cccccc}
\hline Variables & N & Minimum & Maximum & Mean & Std. Deviation \\
\hline ROA & 7483 & -114.520 & 52.290 & 3.212 & 6.250 \\
ROCE & 7483 & -136.810 & 79.400 & 4.508 & 9.098 \\
RPNW & 7483 & -2724.320 & 622.370 & 5.305 & 50.751 \\
AS & 7483 & 0.016 & 2.785 & 0.754 & 0.327 \\
COFD & 7483 & -983706.557 & 127400.000 & -173.950 & 12050.153 \\
GO & 7483 & -3578.304 & 120591.927 & 19.432 & 1402.640 \\
SIZE & 7483 & 1.525 & 6.738 & 3.599 & 0.848 \\
TTAX & 7483 & 0.000 & 969658.200 & 2635.373 & 21088.215 \\
LEV & 7483 & 0.000 & 664.750 & 1.745 & 10.635
\end{tabular}




\subsection{Correlation matrix}

Results in table 3 show that there is a negative association between AS, LEV, and the profitability of Indian firms measured by ROA and ROCE. On the contrary, COFD, GO, SIZE, TTAX, and LEV have a positive relationship with ROA, ROCE, and RONW. Notably, it is noticed that the relationship between firms' specific and RONW is weak. Furthermore, form table 3 we can see that there is no high correlation coefficient between the independent variables, which means that there is no multi collinearly between the variables of the study.

Table 3. Correlation matrix

\begin{tabular}{cccccccccc}
\hline Variables & ROA & ROCE & RPNW & AS & COFD & GO & SIZE & TTAX & LEV \\
\hline ROA & 1 & $.972^{* *}$ & $.394^{* *}$ & $-.059^{* *}$ & $.039^{* *}$ & -.005 & $.108^{* *}$ & $.075^{* *}$ & $-.133^{* *}$ \\
ROCE & $.972^{* *}$ & 1 & $.404^{* *}$ & $-.072^{* *}$ & $.033^{* *}$ & -.005 & $.105^{* *}$ & $.085^{* *}$ & $-.132^{* *}$ \\
RPNW & $.394^{* *}$ & $.404^{* *}$ & 1 & .000 & .009 & -.001 & .000 & $.023^{*}$ & $-.388^{* *}$ \\
AS & $-.059^{* *}$ & $-.072^{* *}$ & .000 & 1 & -.007 & .001 & $-.271^{* *}$ & $-.051^{* *}$ & .019 \\
COFD & $.039^{* *}$ & $.033^{* *}$ & .009 & -.007 & 1 & .000 & $.023^{*}$ & .002 & .002 \\
GO & -.005 & -.005 & -.001 & .001 & .000 & 1 & -.004 & -.002 & -.001 \\
SIZE & $.108^{* *}$ & $.105^{* *}$ & .000 & $-.271^{* *}$ & $.023^{*}$ & -.004 & 1 & $.285^{* *}$ & .009 \\
TTAX & $.075^{* *}$ & $.085^{* *}$ & $.023^{*}$ & $-.051^{* *}$ & .002 & -.002 & $.285^{* *}$ & 1 \\
LEV & $-.133^{* *}$ & $-.132^{* *}$ & $-.388^{* *}$ & .019 & .002 & -.001 & .009 & -.010 & -.010 \\
$* *$ Correlation is significant at the 0.01 level (2-tailed). & & & & &
\end{tabular}

\subsection{Regression analysis}

Table 4 shows the panel diagnostic tests: Redundant Fixed Effects Tests and Correlated Random Effects Hausman Test. Redundant Fixed Effects Tests are used to find out whether the models have one or two ways intercept; the tests show that the three models have two ways intercept as long as the Probability value of Crosssection and period is less than 0.05. On the other hand, Hausman Test is used to choose whether to go for oneway variable or two variables intercept model. The test indicates that fixed effect model is abbreviate for the analysis.

Table 4. Panel diagnostic tests

\begin{tabular}{|c|c|c|c|c|c|c|c|c|}
\hline \multicolumn{9}{|c|}{ Redundant Fixed Effects Tests } \\
\hline \multicolumn{3}{|c|}{ ROA } & \multicolumn{3}{|c|}{ ROCE } & \multicolumn{3}{|c|}{ RONW } \\
\hline Effects Test & Statistic & $\begin{array}{l}\mathrm{P} \\
\text { rob. }\end{array}$ & Effects Test & Statistic & $\begin{array}{l}\mathrm{P} \\
\text { rob. }\end{array}$ & Effects Test & Statistic & $\begin{array}{l}\mathrm{P} \\
\text { rob. }\end{array}$ \\
\hline $\begin{array}{l}\text { Cross- } \\
\text { section F }\end{array}$ & $\begin{array}{c}7.32005 \\
4\end{array}$ & 0 & $\begin{array}{l}\text { Cross- } \\
\text { section F }\end{array}$ & 7.63293 & 0 & $\begin{array}{r}\text { Cross- } \\
\text { section F }\end{array}$ & $\begin{array}{c}7.32005 \\
4\end{array}$ & 0 \\
\hline Period F & $\begin{array}{c}22.0463 \\
4\end{array}$ & 0 & Period F & $\begin{array}{l}22.4842 \\
82\end{array}$ & 0 & Period F & $\begin{array}{c}22.0463 \\
4\end{array}$ & 0 \\
\hline \multicolumn{9}{|c|}{ Correlated Random Effects - Hausman Test } \\
\hline \multicolumn{3}{|c|}{ ROA } & \multicolumn{3}{|c|}{ ROCE } & \multicolumn{3}{|c|}{ RONW } \\
\hline $\begin{array}{c}\text { Test } \\
\text { Summary }\end{array}$ & $\begin{array}{l}\text { Chi-Sq. } \\
\text { Statistic }\end{array}$ & $\begin{array}{l}\mathrm{P} \\
\text { rob. }\end{array}$ & $\begin{array}{c}\text { Test } \\
\text { Summary }\end{array}$ & $\begin{array}{l}\text { Chi-Sq. } \\
\text { Statistic }\end{array}$ & $\begin{array}{l}\mathrm{P} \\
\text { rob. }\end{array}$ & $\begin{array}{c}\text { Test } \\
\text { Summary }\end{array}$ & $\begin{array}{l}\text { Chi-Sq. } \\
\text { Statistic }\end{array}$ & $\begin{array}{l}\mathrm{P} \\
\text { rob. }\end{array}$ \\
\hline $\begin{array}{l}\text { Cross- } \\
\text { section } \\
\text { random }\end{array}$ & $\begin{array}{l}158.394 \\
6\end{array}$ & 0 & $\begin{array}{l}\text { Cross- } \\
\text { section } \\
\text { random }\end{array}$ & $\begin{array}{c}147.440 \\
4\end{array}$ & 0 & $\begin{array}{l}\text { Cross- } \\
\text { section } \\
\text { random }\end{array}$ & $\begin{array}{c}158.394 \\
6\end{array}$ & 0 \\
\hline
\end{tabular}

\section{a. Impact of firms specific on return on assets}

Model 1 in the table (5) represents the impact of firms' specific on the financial performance of Indian firms. Results of fixed effect model show that the $\mathrm{R}^{2}$ and adjusted $\mathrm{R}^{2}$ are fairly good, $\mathrm{R}^{2}$ is 0.56 , which means that 0.56 of the variation in return on assets of Indian firms is attributable jointly by AS, COFD, GO, SIZE, TTAX, and $\mathrm{LEV}$, while the rest of variation in return on assets of Indian firms can be explained by another variable which 
are not included in this study. It is clear from table 5 that COFD, GO, SIZE, and TTAX has a positive and significant impact on return on assets of Indian firms. On the contrary, AS and LEV have a negative and significant impact on return on asset.

Table 5. Regression models results

\begin{tabular}{|c|c|c|c|c|c|c|c|c|c|}
\hline \multicolumn{10}{|c|}{ ROA Regression model } \\
\hline \multirow[b]{2}{*}{ Variable } & \multicolumn{3}{|c|}{ Leas square model } & \multicolumn{3}{|c|}{ Fixed effect model } & \multicolumn{3}{|c|}{ Random effect model } \\
\hline & Coefficient & $\begin{array}{l}\text { Std. } \\
\text { Error }\end{array}$ & Prob. & Coefficient & $\begin{array}{l}\text { Std. } \\
\text { Error }\end{array}$ & Prob. & Coefficient & $\begin{array}{l}\text { Std. } \\
\text { Error }\end{array}$ & Prob. \\
\hline AS & -0.579 & 0.226 & 0.010 & -5.016 & 0.488 & 0.000 & -2.245 & 0.332 & 0.000 \\
\hline COFD & 0.000 & 0.000 & 0.001 & 0.000 & 0.000 & 0.032 & 0.000 & 0.000 & 0.008 \\
\hline GO & 0.000 & 0.000 & 0.652 & 0.000 & 0.000 & 0.018 & 0.000 & 0.000 & 0.073 \\
\hline SIZE & 0.641 & 0.091 & 0.000 & -3.048 & 0.494 & 0.000 & 0.209 & 0.160 & 0.191 \\
\hline TTAX & 0.000 & 0.000 & 0.000 & 0.000 & 0.000 & 0.016 & 0.000 & 0.000 & 0.001 \\
\hline LEV & -0.078 & 0.007 & 0.000 & -0.031 & 0.006 & 0.000 & -0.039 & 0.005 & 0.000 \\
\hline \multirow[t]{6}{*}{$\mathrm{C}$} & 1.447 & 0.411 & 0.000 & 17.983 & 1.888 & 0.000 & 4.182 & 0.691 & 0.000 \\
\hline & $\mathrm{R}$-squared & & 0.034 & \multicolumn{3}{|c|}{0.564836} & \multicolumn{3}{|c|}{0.018} \\
\hline & justed R-squared & & 0.033 & \multicolumn{3}{|c|}{0.491901} & \multicolumn{3}{|c|}{0.017} \\
\hline & F-statistic & & 43.764 & \multicolumn{3}{|c|}{7.744397} & \multicolumn{3}{|c|}{22.223} \\
\hline & rob(F-statistic) & & 0.000 & \multicolumn{3}{|c|}{0} & \multicolumn{3}{|c|}{0.000} \\
\hline & rbin-Watson stat & & 0.742 & & .598116 & & \multicolumn{3}{|c|}{1.339} \\
\hline \multicolumn{7}{|c|}{ sion model } & & & \\
\hline & \multicolumn{3}{|c|}{ Leas square model } & \multicolumn{3}{|c|}{ Fixed effect model } & \multicolumn{3}{|c|}{ Random effect model } \\
\hline Variable & Coefficient & $\begin{array}{l}\text { Std. } \\
\text { Error }\end{array}$ & Prob. & Coefficient & $\begin{array}{l}\text { Std. } \\
\text { Error }\end{array}$ & Prob. & Coefficient & $\begin{array}{l}\text { Std. } \\
\text { Error }\end{array}$ & Prob. \\
\hline AS & -1.280 & 0.329 & 0.000 & -7.085 & 0.701 & 0.000 & -3.510 & 0.484 & 0.000 \\
\hline COFD & 0.000 & 0.000 & 0.006 & 0.000 & 0.000 & 0.063 & 0.000 & 0.000 & 0.022 \\
\hline GO & 0.000 & 0.000 & 0.654 & 0.000 & 0.000 & 0.048 & 0.000 & 0.000 & 0.137 \\
\hline SIZE & 0.814 & 0.132 & 0.000 & -4.713 & 0.710 & 0.000 & 0.158 & 0.235 & 0.500 \\
\hline TTAX & 0.000 & 0.000 & 0.000 & 0.000 & 0.000 & 0.001 & 0.000 & 0.000 & 0.000 \\
\hline LEV & -0.113 & 0.010 & 0.000 & -0.044 & 0.008 & 0.000 & -0.056 & 0.008 & 0.000 \\
\hline \multirow[t]{6}{*}{$\mathrm{C}$} & 2.676 & 0.598 & 0.000 & 26.820 & 2.715 & 0.000 & 6.610 & 1.013 & 0.000 \\
\hline & R-squared & & 0.035 & \multicolumn{3}{|c|}{0.575} & \multicolumn{3}{|c|}{0.019} \\
\hline & justed R-squared & & 0.034 & & 0.504 & & & 0.018 & \\
\hline & F-statistic & & 44.914 & & 8.079 & & & 23.497 & \\
\hline & $\operatorname{rob}($ F-statistic) & & 0.000 & & 0.000 & & & 0.000 & \\
\hline & rbin-Watson stat & & 0.708 & & 1.562 & & & 1.311 & \\
\hline & & & & NW Regress & on model & & & & \\
\hline & Leas $\mathrm{S}$ & uare m & & Fixed & effect mo & & Randc & m effect I & \\
\hline Variable & Coefficient & $\begin{array}{l}\text { Std. } \\
\text { Error }\end{array}$ & Prob. & Coefficient & $\begin{array}{l}\text { Std. } \\
\text { Error }\end{array}$ & Prob. & Coefficient & $\begin{array}{c}\text { Std. } \\
\text { Error }\end{array}$ & Prob. \\
\hline AS & 1.242 & 1.719 & 0.470 & -11.803 & 4.782 & 0.014 & 0.763 & 1.802 & 0.672 \\
\hline COFD & 0.000 & 0.000 & 0.349 & 0.000 & 0.000 & 0.641 & 0.000 & 0.000 & 0.367 \\
\hline GO & 0.000 & 0.000 & 0.891 & 0.000 & 0.000 & 0.733 & 0.000 & 0.000 & 0.960 \\
\hline SIZE & 0.003 & 0.691 & 0.996 & -13.020 & 4.845 & 0.007 & -0.119 & 0.733 & 0.871 \\
\hline TTAX & 0.000 & 0.000 & 0.079 & 0.000 & 0.000 & 0.380 & 0.000 & 0.000 & 0.080 \\
\hline LEV & -1.852 & 0.051 & 0.000 & -1.141 & 0.054 & 0.000 & -1.717 & 0.049 & 0.000 \\
\hline $\mathrm{C}$ & 7.474 & 3.127 & 0.017 & 62.932 & 18.512 & 0.001 & 8.035 & 3.304 & 0.015 \\
\hline & R-squared & & 0.151 & & 0.365 & & & 0.133 & \\
\hline & justed R-squared & & 0.150 & & 0.259 & & & 0.132 & \\
\hline & F-statistic & & 221.915 & & 3.432 & & & 191.088 & \\
\hline & rob(F-statistic) & & 0.000 & & 0.000 & & & 0.000 & \\
\hline & rbin-Watson stat & & 1.577 & & 1.821 & & & 1.617 & \\
\hline
\end{tabular}

\section{b. Impact of firms specific on return on capital employed}

Model 1 in a table (5) represents the impact of firms' specific on the financial performance of Indian firms. Results of fixed effect model show that the $R^{2}$ and adjusted $R^{2}$ are fairly good, $R^{2}$ is 0.365 which means that 0.365 of the variation in return on assets of Indian firms is attributable jointly by AS, COFD, GO, SIZE, TTAX, and LEV, while the rest of variation in return on capital employed of Indian firms can be explained by other variables which are not included in this study. It is clear from table 5 that COFD, GO, and TTAX has a positive and significant impact on return on capital employed of Indian firms. On the contrary, AS, size, and LEV have a negative and significant impact on return on capital employed. 


\section{c. Impact of firms specific on return on net worth}

Model 1 in table (5) represents the impact of firms' specific on the financial performance of Indian firms. Results of fixed effect model show that the $\mathrm{R}^{2}$ and adjusted $\mathrm{R}^{2}$ are fairly good; $\mathrm{R} 2$ is 0.56 which means that 0.56 of the variation in return on net worth of Indian firms is attributable jointly by AS, COFD, GO, SIZE, TTAX and LEV, while the rest of variation in return on net worth of Indian firms can be explained by another variables which are not included in this study. It is clear from table AS, size, leverage negatively and significantly impact return on net worth and the rest of the variables has an insignificant impact on return on net worth.

\section{Conclusion}

The main aim of this article is to examine the effect of forms' specific on the financial performance of Indian firms. The target population of the study is all non-financial firms listed on Bombay stock exchange; there are almost 4056 non-financial firms listed on Bombay stock exchange. The study eliminated firms that do not have data for the study period from 2011 to 2017 and studies that have mission values, there for the final sample of the study is 1069 firms which do not have even one single missing value. Financial data are extracted from ProwessQ database. The study found that cost of financial distress, growth opportunities, firms size, and total taxes positively and significantly impact the financial performance of Indian firms measured by return on assets and return on capital employed. On the contrary, asset structure and leverage negatively and significantly impact the financial performance of Indian firms. Most of the previous studies were based on small samples; this article bridges an existing gap in the literature by covering large data of 1069 firms for seven years, which make the results of the study to be generalized. The findings of this study have useful implications for policymakers, practitioners and academicians.

\section{References}

[1] Al Maqtari, F. A., Farhan, N. H., Al-Hattami, H. M., \& Khalid, A. S. (2020). Impact of country-level corporate governance on entrepreneurial conditions. Cogent Business \& Management, 7(1), 1797261. https://doi.org/10.1080/23311975.2020.1797261

[2] Al-Homaidi, E. A., Almaqtari, F. A., Yahya, A. T., \& Khaled, A. S. (2020). Internal and external determinants of listed commercial banks' profitability in India: dynamic GMM approach. International Journal of Monetary Economics and Finance, 13(1), 34-67.

[3] Al-Homaidi, E. A., Tabash, M. I., Farhan, N. H., \& Almaqtari, F. A. (2018). Bank-specific and macroeconomic determinants of profitability of Indian commercial banks: A panel data approach. Cogent Economics \& Finance, 6(1), 1548072.

[4] Al-Jafari, M. K., \& Alchami, M. (2014). Determinants of bank profitability: Evidence from Syria. Journal of Applied Finance and Banking, 4(1), 1-17.

[5] Al-Jafari, M. K., \& Samman, H. A. (2015). Determinants of profitability: evidence from industrial companies listed on Muscat Securities Market. Rev. Eur. Stud., 7 (11) 303 - 311

[6] Almaqtari, F. A., Al-Hattami, H. M., Al-Nuzaili, K. M., \& Al-Bukhrani, M. A. (2020). Corporate governance in India: A systematic review and synthesis for future research. Cogent Business \& Management, 7(1), 1803579. https://doi.org/10.1080/23311975.2020.1803579

[7] Almaqtari, F. A., Al-Homaidi, E. A., Tabash, M. I., \& Farhan, N. H. (2019). The determinants of profitability of Indian commercial banks: A panel data approach. International Journal of Finance \& Economics, 24(1), 168-185.

[8] Almaqtari, F. A., Farhan, N. H., Yahya, A. T., \& Al-Homaidi, E. A. (2020). Macro and socio-economic determinants of firms' financial performance: empirical evidence from Indian states. International Journal of Business Excellence, 21(4), 488-512.

[9] Almaqtari, F. A., Hashed, A. A., Shamim, M., \& Al-ahdal, W. M. (2020). Impact of corporate governance mechanisms on financial reporting quality: a study of Indian GAAP and Indian Accounting Standards. Problems and Perspectives in Management, 18(4), 1.-13. https://doi.org/10.21511/ppm.18(4).2020.01 
[10] Almaqtari, F. A., Shamim, M., Al-Hattami, H. M., \& Aqlan, S. A. (2020). Corporate governance in India and some selected Gulf countries. International Journal of Managerial and Financial Accounting, 12(2), 165-185. https://doi.org/10.1504/IJMFA.2020.109135

[11] Bashar, S. M., \& Islam, M. I. (2014). Determinants of profitability in the pharmaceutical industry of Bangladesh. Journal of SUB, 5(1), 56-76.

[12] Bhayani, S. J. (2010). Determinant of Profitability in Indian Cement Industry: An Economic Analysis. South Asian Journal of Management, 17(4). ,6-20.

[13] Bobáková, I. V. (2003). Raising the profitability of commercial banks. Biatec, 11 April , 21-25.

[14] Bobáková, I. V. (2003). Raising the profitability of commercial banks. Biatec, 11, 21-25.

[15] Charumathi, B. (2012, July). On the determinants of profitability of Indian life insurers-an empirical study. In Proceedings of the world congress on Engineering 1 (2) 4-6.

[16] Chinaemerem, Osuji,. C., \& Anthony, Odita. (2012). Impact of capital structure on the financial performance of Nigerian firms. Arabian Journal of Business and Management Review (OMAN Chapter), 1(12), 43.

[17] Daare, W. J. (2016). Determinants of Non-Life insurance companies profitability: an empirical study in India. International Journal of Innovative Research and Advanced Studies, 3(13), 6-11.

[18] Devi, A., \& Devi, S. (2014). Determinants of firms' profitability in Pakistan. Research Journal of Finance and Accounting, 5(19), 87-91.

[19] Farhan, N. H., Alhomidi, E., Almaqtari, F. A., \& Tabash, M. I. (2019). Does Corporate Governance Moderate the Relationship between Liquidity Ratios and Financial Performance? Evidence from Indian Pharmaceutical Companies. Academic Journal of Interdisciplinary Studies, 8(3), 144-144.

[20] Farhan, N., Tabash, M., Almaqtari, F., \& Yahya, A. (2020). Board composition and firms' profitability: Empirical evidence from pharmaceutical industry in India. Journal of International Studies, 13(3), 180194. https://doi.org/10.14254/2071- 8330.2020/13-3/12

[21] Gaur, J., \& Gupta, R. (2011). Comparing firm performance on the basis of age, size, leverage, and group affiliation in Indian IT industry. Romanian Journal of Marketing, (3), 8-13.

[22] Gill, A., \& Mathur, N. (2011). Factors that Influence Financial Leverage of Canadian Saccos. Journal of Applied Finance \& Banking, 1(2), 19-37.

[23] Gitman, L. J. and Zutter, C.J., 2012. Principles of Managerial Finance, 13th ed., USA: Addison Wesle.

[24] Jónsson, B. (2007). Does the size matter?: the relationship between size and porfitability of Icelandic firms. Bifrost Journal of Social Sciences, 1 Jan, 43-55.

[25] Madrid-Guijarro, A., Auken, H. V., \& García-Pérez-de-Lema, D. (2007). An analysis of factors impacting performance of Spanish manufacturing firms. Journal of Small Business \& Entrepreneurship, 20(4), 369386.

[26] Margaretha, F., \& Supartika, N. (2016). Factors affecting profitability of small medium enterprises (SMEs) firm listed in Indonesia Stock Exchange. Journal of Economics, Business and Management, 4(2), 132-137.

[27] Mistry, D. S. (2012). Determinants of profitability in Indian automotive industry. Tecnia Journal of Management Studies, 7(1), 20-23.

[28] Nunes, P. J. M., Serrasqueiro, Z. M., \& Sequeira, T. N. (2009). Profitability in Portuguese service industries: a panel data approach. The Service Industries Journal, 29(5), 693-707.

[29] Odusanya, I. A., Yinusa, O. G., \& Ilo, B. M. (2018). Determinants of firm profitability in Nigeria: Evidence from dynamic panel models. SPOUDAI-Journal of Economics and Business, 68(1), 43-58.

[30] Ogbulu, O. M., \& Emeni, F. K. (2012). Determinants of corporate capital structure in Nigeria. International Journal of Economics and Management Sciences, 1(10), 81-96.

[31] Olutunla, G. T., \& Obamuyi, T. M. (2008). An empirical analysis of factors associated with the profitability of Small and medium-enterprises in Nigeria. African Journal of business management, 2(11), 195-200. Lazar, S. (2016). Determinants of firm performance: evidence from Romanian listed companies. Review of Economic and Business Studies, 9(1), 53-69.

[32] Pratheepan, T. (2014). A Panel Data Analysis of Profitability Determinants: Empirical Results from Sri Lankan Manufacturing Companies. International Journal of Economics, Commerce and Management, 2(12).1-9 